\title{
Anti-inflammatory effect of tribulusamide D isolated from Tribulus terrestris in lipopolysaccharide-stimulated RAW264.7 macrophages
}

\author{
HYUN HWA LEE ${ }^{1 *}$, EUN-KYUNG AHN ${ }^{2 *}$, SEONG-SU HONG $^{2}$ and JOA SUB OH ${ }^{1}$ \\ ${ }^{1}$ Department of Pharmacy, College of Pharmacy, Dankook University, Cheonan, Chungcheongnam 31116; ${ }^{2}$ Bio-center, \\ Gyeonggi Institute of Science \& Technology Promotion, Suwon, Gyeonggi 443-270, Republic of Korea
}

Received May 18, 2016; Accepted February 27, 2017

DOI: $10.3892 / \mathrm{mmr} .2017 .7208$

\begin{abstract}
Tribulus terrestris (T. terrestris) has been used as a traditional medicine for the treatment of a variety of diseases, including inflammation, edema and hypertension. The aqueous and ethanol extracts of T.terrestris contain alkaloids, flavonoids, tannins, quinines and phenolic compounds. Tribulusamide D is a compound that has been isolated from the ethanol extract of $T$. terrestris. The present study investigated the anti-inflammatory effect of tribulusamide D on lipopolysaccharide (LPS)-stimulated RAW 264.7 macrophages. Tribulusamide D inhibited the production of LPS-induced nitric oxide and prostaglandin $\mathrm{E}_{2}$, by reducing the expression of inducible nitric oxide synthase and cyclooxygenase- 2 expression, respectively. The expression of these genes associated with inflammation was determined using reverse transcription-polymerase chain reaction and western blot analysis. Furthermore, tribulusamide D reduced the expression of LPS-induced inflammatory cytokines, including interleukin (IL)-6, IL-10 and tumor necrosis factor- $\alpha$. They were quantified using an enzyme-linked immunosorbent assay. In addition, the present study confirmed that the inhibitory effects of tribulusamide D on the inflammatory response were
\end{abstract}

Correspondence to: Professor Joa Sub Oh, Department of Pharmacy, College of Pharmacy, Dankook University, 119 Dandae-ro, Dongnam-gu, Cheonan, Chungcheongnam 31116, Republic of Korea

E-mail: jsoh@dankook.ac.kr

${ }^{*}$ Contributed equally

Abbreviations: COX-2, cyclooxygenase-2; iNOS, inducible nitric oxide synthase; IL, interleukin; LPS, lipopolysaccharide; NO, nitric oxide; PG, prostaglandin; PMSF, phenylmethylsulfonyl fluoride; TNF- $\alpha$, tumor necrosis factor- $\alpha$; NF- $\kappa B$, nuclear factor- $\kappa \mathrm{B}$; MAPKs, mitogen-activated protein kinases

Key words: tribulusamide D, anti-inflammatory effect, cyclooxygenase-2, pro-inflammatory cytokines, RAW 264.7 macrophages mediated through inactivation of mitogen-activated protein kinase p38 and inhibition of nuclear localization of nuclear factor-B, which were also determined by western blot analysis. To the best of our knowledge, the current study is the first to demonstrate that tribulusamide $\mathrm{D}$ exerts anti-inflammatory activity by altering the expression of inflammatory mediators and cytokines, indicating that tribulusamide D could be developed as a potential therapeutic agent for the treatment of inflammatory disorders.

\section{Introduction}

Tribulus terrestris L. is an annual creeping herb of the family Zygophyllaceae (1). Since ancient times, it has been used in folk medicine for the treatment of hypertension, edema, eye problems, sexual dysfunction and rheumatoid arthritis (2-8). Previously, it was reported that $T$. terrestris contains steroidal saponins, alkaloids and flavonoids (9) and that the aqueous and ethanol extracts of $T$. terrestris contain alkaloids, flavonoids, tannins, quinines and phenolic compounds (10). A novel compound isolated from the ethanol extract of $T$. terrestris is tribulusamide D (11). However, the molecular mechanisms underlying the anti-inflammatory effects of tribulusamide $\mathrm{D}$ have not previously been reported. Inflammation is an immune response to infection involving biological chemicals and physiological stimuli (12). It causes enhanced vascular permeability, fever and septic shock, thereby increasing the blood flow and migration of immune cells to the sites of infection (13). Macrophages have essential roles during inflammation, including the elimination of foreign organisms and antigen presentation (14). Upon activation of macrophages by lipopolysaccharide (LPS), various inflammatory mediators and inflammatory cytokines, including nitric oxide (NO), prostaglandin (PG) $\mathrm{E}_{2}$, interleukin (IL)-6, IL-10 and tumor necrosis factor- $\alpha$ (TNF- $\alpha)$, are secreted $(15,16)$.

There are three isoforms of nitric oxide synthase (NOS): Neuronal NOS, endothelial NOS and inducible NOS (iNOS). Stimulation of macrophages with LPS induces increased expression of iNOS, which leads to the increased production of NO during an inflammatory response (17). Cyclooxygenase-2 (COX-2) is an enzyme in the PGH synthase family, and its expression is increased by cytokines and bacterial products, 
such as LPS. COX-2 converts arachidonic acid to PGs such as $\mathrm{PGE}_{2}$, which is associated with inflammatory pain and swelling (18-21). These inflammatory mediators (NO and $\mathrm{PGE}_{2}$ ) and cytokines (IL-6, IL-10 and TNF- $\alpha$ ) are implicated in numerous diseases, including rheumatoid arthritis, asthma and atherosclerosis (22). Therefore, reducing $\mathrm{NO}$ and $\mathrm{PGE}_{2}$ release by inhibiting iNOS and COX-2, respectively, may be crucial for the development of novel anti-inflammatory drugs. In addition, Kim et al (23) reported that p38 mitogen-activated protein kinase (p38 MAPK) mediates LPS-induced nuclear factor $-\kappa \mathrm{B}(\mathrm{NF}-\kappa \mathrm{B})$ activation in acute lung injury and RAW264.7 macrophages.

To the best of our knowledge, the present study is the first to demonstrate the anti-inflammatory effect of tribulusamide D, a compound isolated from the ethanolic extract of Tribulus terrestris L., on LPS-stimulated inflammatory responses in RAW 264.7 macrophages.

\section{Materials and methods}

Plant material. The fruits of Tribulus terrestris L. were purchased from the Gyeongdong Oriental Medicine Market (Seoul, Korea) in March 2012, and were identified by Professor Joa Sub Oh (College of Pharmacy, Dankook University, Cheonan, Korea). A voucher specimen (G46) was deposited at the Natural Products Research Institute, Gyeonggi Institute of Science and Technology Promotion (Suwon, Korea).

Preparation of tribulusamide $D$. The air-dried and crushed fruits of T.terrestris L. (10 kg) were ground and extracted with $80 \%$ ethanol $(3 \times 18 \mathrm{~L})$ for 2 days at room temperature. The $80 \%$ ethanol extract was filtered and concentrated under vacuum at $40^{\circ} \mathrm{C}$ to yield $673.5 \mathrm{~g}$ of residue. This residue was then suspended in water and partitioned with hexane (3x1.5 L) to afford a hexane soluble layer (40 g). The aqueous layer was partitioned with chloroform $\left(\mathrm{CHCl}_{3}\right)$ to provide a $\mathrm{CHCl}_{3}$-soluble residue $(10 \mathrm{~g})$. The remaining aqueous layer was partitioned with ethyl acetate to give an ethyl acetate-soluble extract $(8.1 \mathrm{~g})$. The ethyl acetate layer $(8.1 \mathrm{~g})$ was subjected to liquid chromatography on a silica gel column (230-400 mesh; $7 \times 20 \mathrm{~cm})$ using $\mathrm{CHCl}_{3}$ :methanol (100:0, 99:1, 98:2, 97:3, 96:4, 94:6, 92:8, 90:10, 80:20, 70:30, 60:40, 50:50) v/v gradient mixtures as eluents. The eluent fractions G46-51-1-13 were obtained from this initial liquid chromatographic separation. The fractions were examined to an in vitro assay to assess their inhibitory effect on NO production (24).

Among them, the fraction G46-51-7 (2.71 g) exhibited promising inhibitory activity against NO production and it was selected for further investigation. G46-51-7 (2.71 g) was passed through a column containing Sephadex ${ }^{\circledR}$ LH-20 gel using $\mathrm{CHCl}_{3}: \mathrm{MeOH}(1: 1)$ as eluent, to produce sub-fractions (G46-52-1-21). Of the above 21 fractions, tribulusamide D (17.3 mg) was isolated from fraction G46-52-14, which was precipitated with $\mathrm{MeOH}$. ${ }^{1} \mathrm{H}$ - and ${ }^{13} \mathrm{C}$-nuclear magnetic resonance (NMR) spectra were recorded on a Bruker Ascend ${ }^{\mathrm{TM}}$ $700 \mathrm{MHz}$ NMR spectrometer (Bruker Corporation, Billerica, MA, USA) using dimethylsulfoxide (DMSO) as a solvent. Electrospray ionization mass (ESI-MS) was measured on a Thermo Finnigan TSQ Quantum mass spectrometer (Thermo Fisher Scientific, Inc., Waltham, MA, USA).
Tribulusamide D. Tribulusamide D is a white, amorphous powder; ${ }^{1} \mathrm{H}-\mathrm{NMR}$ (DMSO-d6, $\left.700 \mathrm{MHz}\right) \delta: 10.4(1 \mathrm{H}, \mathrm{s}, \mathrm{OH})$, $9.39(1 \mathrm{H}, \mathrm{s}, \mathrm{OH}), 9.16(1 \mathrm{H}, \mathrm{s}, \mathrm{OH}), 8.29(1 \mathrm{H}, \mathrm{t}, \mathrm{J}=5.6 \mathrm{~Hz}, \mathrm{NH})$, $7.90\left(2 \mathrm{H}, \mathrm{d}, \mathrm{J}=8.4 \mathrm{~Hz}, \mathrm{H}-2^{\prime}\right.$ and H-6'), $7.27(1 \mathrm{H}, \mathrm{d}, \mathrm{J}=16.1 \mathrm{~Hz}$, H-7), 6.99 (1H, d, J=2.1 Hz, H-2), 6.88 (2H, d, J=9.1 Hz, H-3' and $\left.\left.\mathrm{H}^{-5}\right)^{\prime}\right), 6.87(1 \mathrm{H}, \mathrm{dd}, \mathrm{J}=8.4,2.1 \mathrm{~Hz}, \mathrm{H}-6), 6.75(1 \mathrm{H}, \mathrm{d}$, J=7.7 Hz, H-5), 6.52 (1H, d, J=15.4 Hz, H-8), 4.65 (2H, s, H-8'); ${ }^{13}$ C-NMR (DMSO-d6, 175 MHz) \& 193.9 (C-7'), 166.2 (C-9), 162.8 (C-4'), 147.9 (C-4), 146.0 (C-3), 140.0 (C-7), 130.9 (C-2'), 130.9 (C-6'), 127.0 (C-1'), 126.8 (C-1), 121.0 (C-6), 118.6 (C-8), 116.2 (C-5), 115.8 (C-3'), 115.8 (C-5'), 114.3 (C-2), 45.9 (C-8'); ESI-MS m/z 312 [M-H]-. The structure of tribulusamide D is presented in Fig. 1A.

Reagents. DMSO (cat. no. D1370) and MTT (cat. no. M1415) were purchased from Duchefa Biochemie B.V (Haarlem, The Netherlands). LPS from Escherichia coli serotype 0111:B4, bovine serum albumin (cat. no. A9647), RIPA buffer (cat. no. R0278), protease inhibitor cocktail (cat. no. P8340), phosphatase inhibitor cocktail (cat. no. P5726) and $\mathrm{N}^{\mathrm{G}}$-methyl-L-arginine acetate salt (L-NMMA) (cat. no. M7033), dexamethasone (cat. no. D4902), Celecoxib (cat. no. PZ0008) were purchased from Sigma-Aldrich; Merck KGaA (Darmstadt, Germany). Cells were treated with L-NMMA $(100 \mu \mathrm{M})$, dexamethasone $(25 \mu \mathrm{M})$ and celecoxib $(5 \mu \mathrm{M})$ for $1 \mathrm{~h}$ prior to LPS $(0.5 \mu \mathrm{g} / \mathrm{ml})$ stimulation for $24 \mathrm{~h}$.

Image-iT $^{\mathrm{TM}}$ FX Signal Enhancer, Alexa Fluor ${ }^{\circledR}$ 488-conjugated secondary antibody (goat anti-mouse, Thermo Fisher Scientific, Waltham, MA, USA, cat. no. A32723), ProLong ${ }^{\circledR}$ Gold Antifade reagent with DAPI (Thermo Fisher Scientific, Inc., cat. no. P36931). Anti- $\beta$-actin (cat. no. 5125), anti-phospho-JNK (T183/Y185) (cat. no. 4668), anti-JNK (cat. no. 9252), anti-phospho-extracellular signal-regulated kinase (ERK; T202/Y204) (cat. no. 9101), anti-ERK (cat. no. 9102), anti-phospho-p38 (T180/Y182) (cat. no. 9211) and anti-p38 (cat. no. 9212) primary antibodies were obtained from Cell Signaling Technology, Inc. (Danvers, MA, USA) and anti-iNOS antibody was purchased from Abcam (Cambridge, UK) (cat. no. ab3523). Anti-COX2 (cat. no. sc-376861), anti-NF-кB p65 (cat. no. sc-7151) and anti-lamin B (cat. no. sc-6216) antibodies, and goat (cat. no. sc-2354) and rabbit (cat. no. sc-2004) IgG-horseradish peroxidase conjugated secondary antibodies were obtained from Santa Cruz Biotechnology, Inc. (Dallas, TX, USA).

Cell culture conditions. RAW 264.7 mouse macrophage cells (TIB-71) were purchased from the American Type Culture Collection (Manassas, VA, USA). Cells were maintained in Dulbecco's modified Eagle's medium supplemented with 10\% fetal bovine serum (FBS) (Gibco; Thermo Fisher Scientific, Inc.), $100 \mathrm{U} / \mathrm{ml}$ penicillin and $0.1 \mathrm{mg} / \mathrm{ml}$ streptomycin (Invitrogen; Thermo Fisher Scientific, Inc.) in a humidified atmosphere of $95 \%$ air with $5 \% \mathrm{CO}_{2}$ at $37^{\circ} \mathrm{C}$.

NO production assay. RAW 264.7 cells were seeded in 96-well plates $\left(4 \times 10^{4}\right.$ cells/well) and were treated with tribulusamide D (25-100 $\mu \mathrm{M})$ for $1 \mathrm{~h}$ prior to LPS $(0.5 \mu \mathrm{g} / \mathrm{ml})$ stimulation for $24 \mathrm{~h}$. The negative control was treated with serum-free media (SFM; Gibco; Thermo Fisher Scientific, Inc.). 
A
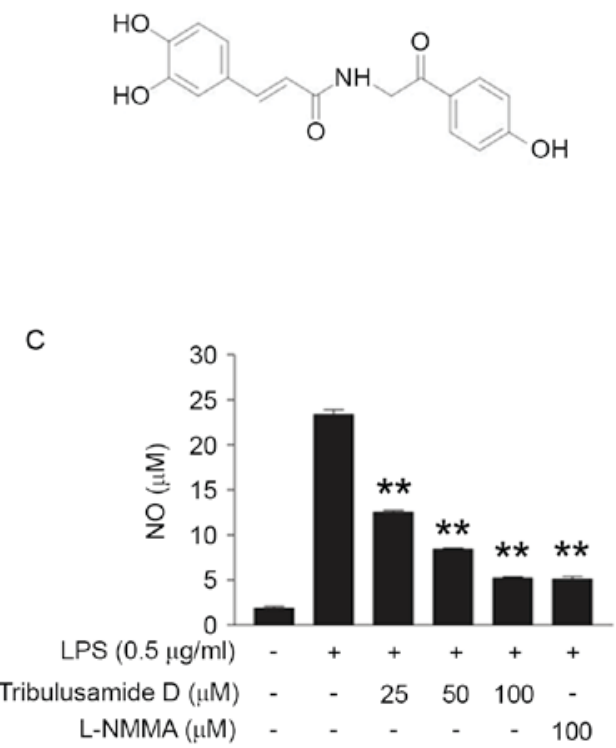

B

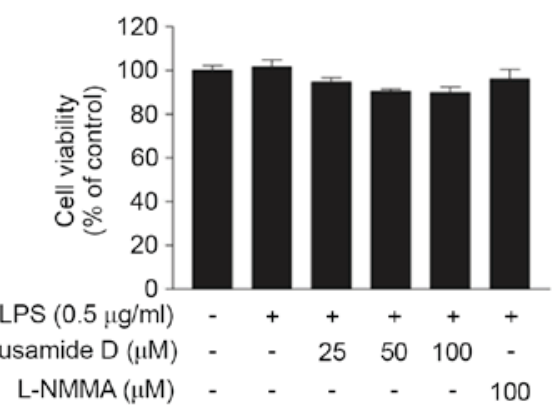

D

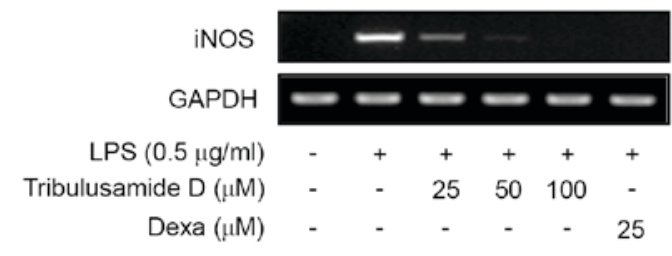

$E$

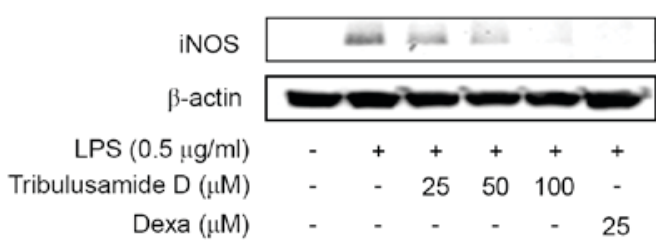

Figure 1. Regulatory effects of tribulusamide D on NO production and iNOS expression in LPS-stimulated RAW 264.7 cells. Cells were treated with tribulusamide D $(25-100 \mu \mathrm{M})$ for $1 \mathrm{~h}$ prior to LPS $(0.5 \mu \mathrm{g} / \mathrm{ml})$ stimulation for $24 \mathrm{~h}$. (A) Chemical structure of tribulusamide D. (B) Cytotoxicity was determined by MTT assay and (C) NO assay was performed using Griess reagent. L-NMMA (100 $\mu \mathrm{M})$ was used as a positive control. (D) Expression of iNOS mRNA was determined by reverse transcription-polymerase chain reaction analysis. (E) Expression of iNOS protein was determined by western blot analysis. Data are presented as the mean \pm standard deviation of three independent experiments. ${ }^{* *} \mathrm{P}<0.01 \mathrm{vs.} \mathrm{LPS}$-treated cells. NO, nitric oxide; iNOS, inducible nitric oxide synthase; LPS, lipopolysaccharide; L-NMMA, $\mathrm{N}^{\mathrm{G}}$-methyl-L-arginine acetate salt; Dexa, dexamethasone.

The amount of nitrite, a stable metabolite of NO, was measured by using Griess reagent (1\% sulfanilamide and $0.1 \%$ naphthylethylenediamine dihydrochloride in $2.5 \%$ phosphoric acid; EMD Millipore, Billerica, MA, USA). Absorbance was subsequently measured at $540 \mathrm{~nm}$, using a SpectraMax 190PC microplate reader (Molecular Devices, LLC, Sunnyvale, CA, USA). The quantity of nitrite was determined from a standard curve for sodium nitrite (Sigma-Aldrich; Merck KGaA).

Cell cytotoxicity assay. RAW264.7 cells were plated at a density of $4 \times 10^{4}$ cells/well in 96 -well plates. Cells were treated with tribulusamide $\mathrm{D}(25-100 \mu \mathrm{M})$ for $1 \mathrm{~h}$ prior to LPS $(0.5 \mu \mathrm{g} / \mathrm{ml})$ stimulation for $24 \mathrm{~h}$. MTT $(5 \mathrm{mg} / \mathrm{ml}$ in PBS) was added to each well and incubated for $90 \mathrm{~min}$. The medium was removed from the wells by aspiration, $0.1 \mathrm{ml}$ buffered DMSO was added to each well and the plate was shaken. The absorbance of each well was measured at a wavelength of $540 \mathrm{~nm}$ using a SpectraMax 190PC microplate reader. Data are presented as the mean \pm standard deviation of three replicates.

ELISA. ELISA was performed to determine the concentration of cytokines in RAW 264.7 cells in vitro. RAW264.7 cells were plated at a density of $4 \times 10^{4}$ cells/well in 96-well plates and treated with tribulusamide $\mathrm{D}(25-100 \mu \mathrm{M})$ for $1 \mathrm{~h}$ prior to LPS $(0.5 \mu \mathrm{g} / \mathrm{ml})$ stimulation for $24 \mathrm{~h}$.

Levels of IL-6, IL-10 and TNF- $\alpha$ in culture medium were quantified using platinum IL-6 (cat. no. BMS603/2), IL-10 (cat. no. BMS614/2), TNF- $\alpha$ (cat. no. BMS607/3) ELISA kits (eBioscience, Inc., San Diego, CA, USA), and the $\mathrm{PGE}_{2}$ (cat. no. KGE004B) concentration in culture medium was quantified using a competitive enzyme ELISA kit (R\&D Systems, Inc., Minneapolis, MN, USA), according to the manufacturer's instructions.

Reverse transcription-polymerase chain reaction (RT-PCR). RAW264.7 cells were plated at a density of $1 \times 10^{6}$ cells/well in 6 -well plates and treated with tribulusamide D $(25-100 \mu \mathrm{M})$ for $1 \mathrm{~h}$ prior to LPS $(0.5 \mu \mathrm{g} / \mathrm{ml})$ stimulation for $24 \mathrm{~h}$. The total RNA was extracted using TRIzol reagent (Invitrogen; Thermo Fisher Scientific, Inc.) according to the manufacturer's protocol. The integrity of the RNA was evaluated using $1 \%$ agarose gel electrophoresis and ethidium bromide staining. Briefly, $1 \mu \mathrm{g}$ RNA was used as a template for each RT-PCR, using the SuperScript ${ }^{\circledR}$ III First-Strand Synthesis System and Taq DNA polymerase (Invitrogen; Thermo Fisher Scientific, Inc.). Invitrogen Platinum PCR SuperMix (Thermo Fisher Scientific, Inc.) was used which contains DNA polymerase. 
Table I. Primer sequences used for reverse transcription-polymerase chain reaction.

\begin{tabular}{lllc}
\hline & \multicolumn{2}{c}{ Primer sequences } & Accession \\
Target & \multicolumn{1}{c}{ Sense } & Antisense & number \\
\cline { 2 - 4 } GAPDH & 5'-GTATGACTCCACTCACGGCAAA-3' & 5'-GGTCTCGCTCCTGGAGAGATG-3' & NM_008084 \\
IL-6 & 5'-CACTTCACAAGTCGGAGGCTT-3' & 5'-GCAAGTGCATCATCGTTGTTC-3' & NM_031168 \\
IL-10 & 5'-CCTGGTAGAAGTGATGCCCCAGGCA-3' & 5'-CTATGCAGTTGATGAAGATGTCAAA-3' & NM_010548 \\
COX-2 & 5'-GGAGAGACTATCAAGATAGTGATC-3' & 5'-ATGGTCAGTAGACTTTTACAGCTC-3' & NM_011198 \\
TNF- $\alpha$ & 5'-AGCCTGTAGCCCACGTCGTA-3' & 5'-TCTTTGAGATCCATGCCGTTG-3' & NM_013693 \\
iNOS & 5'-ATC TGG ATC AGG AAC CTG AA-3' & 5'-CCT TTT TTG CCC CAT AGG AA-3' & NM_0109273
\end{tabular}

IL, interleukin; COX-2, cyclooxygenase-2; TNF- $\alpha$, tumor necrosis factor- $\alpha$; iNOS, inducible nitric oxide synthase.

A

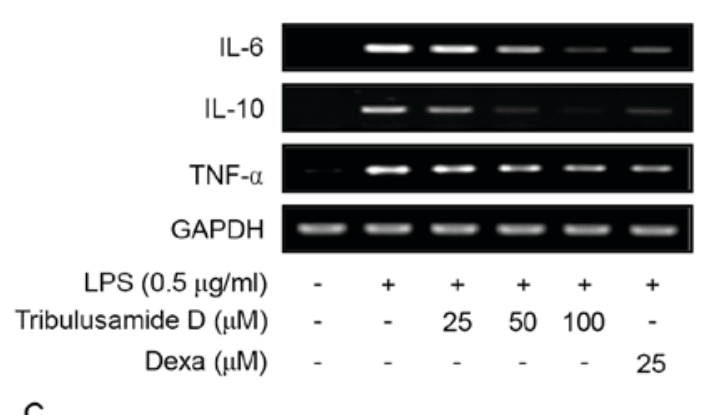

C

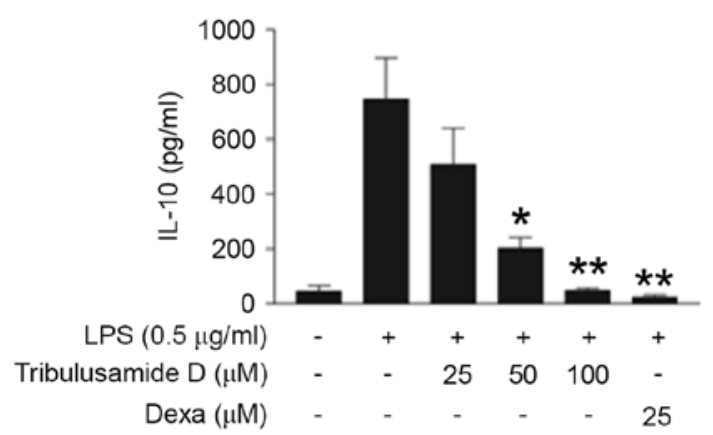

B

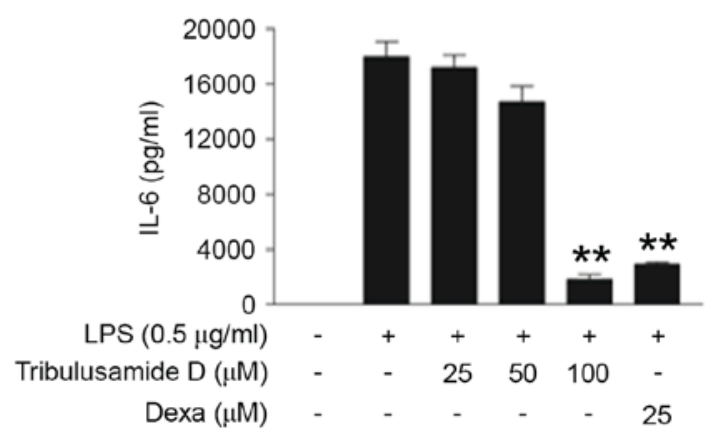

D

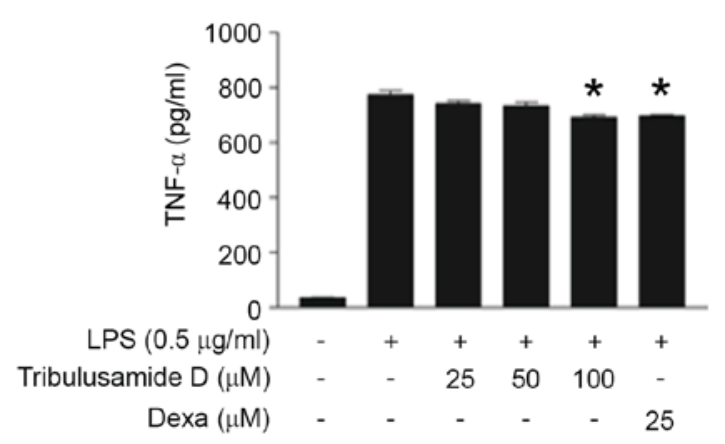

Figure. 2. Regulatory effect of tribulusamide D on the production of IL-6, IL-10 and TNF- $\alpha$ in LPS-stimulated RAW 264.7 cells. Cells were treated with tribulusamide D $(25-100 \mu \mathrm{M})$ for $1 \mathrm{~h}$ prior to LPS $(0.5 \mu \mathrm{g} / \mathrm{ml})$ stimulation for $24 \mathrm{~h}$. (A) Expression of IL-6, IL-10 and TNF- $\alpha$ mRNA was determined by reverse transcription-polymerase chain reaction analysis. ELISA was performed on cell culture supernatants to examine protein levels of (B) IL-6, (C) IL-10 and (D) TNF- $\alpha$ cytokines. Data are presented as the mean \pm standard deviation of three independent experiments. ${ }^{*} \mathrm{P}<0.05$; ${ }^{* *} \mathrm{P}<0.01 \mathrm{vs}$. LPS-treated cells. IL, interleukin; TNF- $\alpha$, tumor necrosis factor- $\alpha$; LPS, lipopolysaccharide; Dexa, dexamethasone.

RT-PCR amplification was performed in My Gene Series Peltier Thermal Cycler (Long Gene Scientific Instruments, Hangzhou, China), using and AccuPower Pfu PCR premix (Bioneer Corporation, Daejeon, Korea). PCR conditions were as follows for 25 cycles: $30 \mathrm{sec}$ denaturation at $95^{\circ} \mathrm{C}, 40 \mathrm{sec}$ annealing between at 55 and $60^{\circ} \mathrm{C}, 60 \mathrm{sec}$ extension at $72^{\circ} \mathrm{C}$, and for final extension of $10 \mathrm{~min}$. The final PCR products were electrophoresed in $1 \%$ agarose gel and stained with ethidium bromide. Images of the bands were captured using a Chemidoc XRS system (Bio-Rad Laboratories, Hercules, CA, USA) and observed using the Quantity One software version 4.6.3. The results compared with the housekeeping gene GAPDH. They were performed at least in triplicate. The sequences of the primers used for RT-PCR are shown in Table I.

Western blot analysis. RAW264.7 cells were plated at a density of $1 \times 10^{6}$ cells/well in 6-well plates and treated with tribulusamide D $(25-100 \mu \mathrm{M})$ for $1 \mathrm{~h}$ prior to LPS $(0.5 \mu \mathrm{g} / \mathrm{ml})$ stimulation for different time points, as indicated. Cells were harvested and washed with PBS, and collected by centrifugation at $16,000 \mathrm{x}$ g for $1 \mathrm{~min}$ at $4^{\circ} \mathrm{C}$. To obtain the cellular lysate, cells were lysed on ice for $30 \mathrm{~min}$ in a RIPA buffer $[50 \mathrm{mM}$ Tris- $\mathrm{HCl}$, $\mathrm{pH} 7.5,0.15 \mathrm{M} \mathrm{NaCl}, 1 \% \mathrm{NP}-40,0.1 \%$ sodium SDS, $1 \mathrm{mM}$ dithiothreitol (DTT) and $1 \mathrm{mM}$ phenylmethylsulfonyl fluoride 
(PMSF)], which contained protease inhibitors (Sigma-Aldrich; Merck KGaA). Total protein was quantified with the Quick Start Bradford 1x Dye reagent (Bio-Rad Laboratories) using bovine serum albumin (BSA, Sigma-Aldrich; Merck KGaA) for the standard. Protein extracts representing $40 \mu \mathrm{g}$ total protein were separated on $10 \%$ SDS-PAGE gel using the BioRad Mini Protean 3 System (Bio-Rad Laboratories) and electroblotted onto Protran nitrocellulose membranes (Whatman; GE Healthcare Life Sciences, Chalfont, UK). Membranes were blocked in 5\% BSA in PBS/0.025\% Tween-20 (Sigma-Aldrich; Merck $\mathrm{KGaA}$ ) for $1 \mathrm{~h}$ at room temperature. The primary antibodies used were specific for $\beta$-actin, p-JNK, JNK, p-ERK, ERK, p-p38, p38 (Cell Signaling Technology), iNOS (Abcam), COX-2, NF- $\mathrm{B}$ p 65 and Lamin B (Santa Cruz Biotechnology, Inc.). The primary antibodies were diluted $(1: 1,000)$ in $5 \%$ BSA in PBST and incubated with the membrane overnight at $4^{\circ} \mathrm{C}$. The secondary antibody was applied at a 1:2,000 dilution in $5 \%$ BSA in PBST and incubated for $1 \mathrm{~h}$ at room temperature then processed for detection with the Supersignal West Pico Chemiluminescent substrate (Thermo Fisher Scientific, Inc.), using a Chemidoc XRS system (Bio-Rad Laboratories) and observed using the Quantity One software version 4.6.3. They were performed at least in triplicate.

Preparation of nuclear extract. RAW264.7 cells were plated at a density of $1 \times 10^{6}$ cells/well in 6-well plates and treated with tribulusamide D $(25-100 \mu \mathrm{M})$ for $1 \mathrm{~h}$ prior to LPS $(0.5 \mu \mathrm{g} / \mathrm{ml})$ stimulation for $30 \mathrm{~min}$. Cells were washed twice with ice-cold PBS prior to trypsinization and centrifugation at $90 \mathrm{x}$ g and $4^{\circ} \mathrm{C}$ for $5 \mathrm{~min}$. Cells were then centrifuged at $20,000 \times \mathrm{g}$ and $4^{\circ} \mathrm{C}$ for $5 \mathrm{~min}$ and resuspended in $200 \mu \mathrm{l}$ buffer (10 mM HEPES at $\mathrm{pH}$ 7.9, $10 \mathrm{mM} \mathrm{KCl}, 1 \mathrm{mM}$ DTT, $0.5 \mathrm{mM}$ PMSF and $0.1 \mathrm{mM}$ EDTA). After incubation on ice for $10 \mathrm{~min}$, cells were lysed by the addition of $12.5 \mu \mathrm{l}$ of $10 \% \mathrm{NP}-40$. Cells were then centrifuged at $20,000 \mathrm{x} \mathrm{g}$ for $2 \mathrm{~min}$ at $4^{\circ} \mathrm{C}$, and the supernatants were collected as cytosolic extract. Pellets were resuspended in $50 \mu \mathrm{l}$ of extraction buffer (20 mM HEPES at pH 7.9, 0.4 M NaCl, $1 \mathrm{mM}$ DTT, $1 \mathrm{mM}$ PMSF, $1 \mathrm{mM}$ EDTA and 1\% NP-40) and incubated on ice for $10 \mathrm{~min}$. Nuclear extract was collected by centrifugation at $15,000 \mathrm{x}$ g for $15 \mathrm{~min}$ at $4^{\circ} \mathrm{C}$. Western blot analysis was performed in the same manner as aforementioned.

Immunofluorescence staining. RAW264.7 cells were cultured on glass cover-slips in 6-well plates with $10 \%$ FBS at a density of $4 \times 10^{5}$ cells/well. Cells were treated with tribulusamide D (25-100 $\mu \mathrm{M})$ for $1 \mathrm{~h}$ prior to LPS $(0.5 \mu \mathrm{g} / \mathrm{ml})$ stimulation for $24 \mathrm{~h}$. The cells were washed with PBS for $5 \mathrm{~min}$, fixed with $4 \%$ formaldehyde for $5 \mathrm{~min}$ on ice, permeabilized with $0.1 \%$ Triton X-100 for $2 \mathrm{~min}$ on ice, washed with PBS for $5 \mathrm{~min}$, and blocked with PBS containing 5\% BSA for $1 \mathrm{~h}$ at room temperature. Primary antibody (COX-2) was incubated for overnight (5\% BSA in PBS; 1:200), washed with PBS, and followed by secondary antibody (Alexa Fluor 488-conjugated, goat anti-mouse) incubation for $1 \mathrm{~h}$ in darkroom (5\% BSA in PBS, 1:300). After washing with PBS, the stained cells were visualized and photographed using a confocal laser scanning microscope (Zeiss AG, Oberkochen, Germany).

Statistical analysis. Statistical analysis was performed using a Student's t-test (Microsoft Excel 2007) and was based on at least three different experiments. $\mathrm{P}<0.05$ was considered to indicate a statistically significant difference.

\section{Results}

Effects of tribulusamide D on LPS-induced NO production and $i N O S$ expression. To determine the cytotoxic effect of tribulusamide D, cells were treated with various concentrations of tribulusamide D $(25,50$ or $100 \mu \mathrm{M})$, which was followed by LPS stimulation $(0.5 \mu \mathrm{g} / \mathrm{ml})$. As demonstrated in Fig. 1B, cell viability was not significantly decreased compared with control cells at concentrations of tribulusamide D up to $100 \mu \mathrm{M}$. Therefore, $25-100 \mu \mathrm{M}$ of tribulusamide D was used in the present study. The anti-inflammatory effect of tribulusamide D on NO production was investigated following treatment with tribulusamide $\mathrm{D}(25-100 \mu \mathrm{M})$ and it was observed that tribulusamide $\mathrm{D}$ reduced $\mathrm{NO}$ production in a concentration-dependent manner. Treatment with $100 \mu \mathrm{M}$ of tribulusamide D decreased NO production by $77.60 \%$ compared with the LPS-only group, which resembled the effect of $100 \mu \mathrm{M}$ of L-NMMA, an inhibitor of NO synthase (Fig. 1C) (25). The present study also investigated whether the effect of tribulusamide D was associated with the expression of iNOS in LPS-stimulated macrophages. As demonstrated in Fig. 1D and E, tribulusamide D treatment reduced LPS-induced expression of iNOS at mRNA and protein levels. The results indicate that tribulusamide D may suppress LPS-induced NO production by downregulating iNOS expression.

Effects of tribulusamide D on LPS-induced expression of IL-6, IL-10 and TNF- $\alpha$ in LPS-stimulated cells. The effect of tribulusamide $\mathrm{D}$ on the expression of the pro-inflammatory cytokines IL-6, IL-10 and TNF- $\alpha$ in LPS-induced RAW 264.7 cells was investigated. As presented in Fig. 2A, LPS treatment markedly induced the mRNA expression of IL-6, IL-10 and TNF- $\alpha$ in RAW 264.7 cells, and tribulusamide D treatment inhibited this increase in a dose-dependent manner. It was confirmed that dexamethasone treatment $(25 \mu \mathrm{M})$, a glucocorticoid class steroid, inhibited the mRNA expression of IL-6, IL-10 and TNF- $\alpha$. In addition the effect of tribulusamide D on the protein expression of IL-6, IL-10 and TNF- $\alpha$ was measured using ELISA kits. Treatment with $100 \mu \mathrm{M}$ of tribulusamide D significantly reduced protein levels of IL-6 (Fig. 2B), IL-10 (Fig. 2C) and TNF- $\alpha$ (Fig. 2D) compared with the LPS-only group, which was similar to the patterns observed for mRNA levels. Collectively, the results demonstrate that tribulusamide D treatment inhibits the expression and release of IL-6, IL-10 and TNF- $\alpha$ at the mRNA and protein level in LPS-stimulated RAW 264.7 cells.

Effects of tribulusamide D on LPS-Induced COX-2 expression and $P G E_{2}$ production. To determine the effects of tribulusamide D on LPS-induced COX-2 expression and $\mathrm{PGE}_{2}$ production, changes in $\mathrm{COX}-2$ expression in LPS-stimulated cells treated with tribulusamide D were examined. As demonstrated in Fig. 3A, tribulusamide D treatment dose-dependently suppressed LPS-induced COX-2 mRNA expression. In addition, western blots revealed that treatment with $100 \mu \mathrm{M}$ tribulusamide D decreased COX-2 protein level (Fig. 3B). Immunofluorescence analysis was also 
A

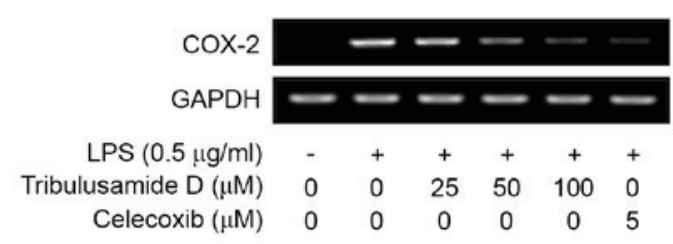

B

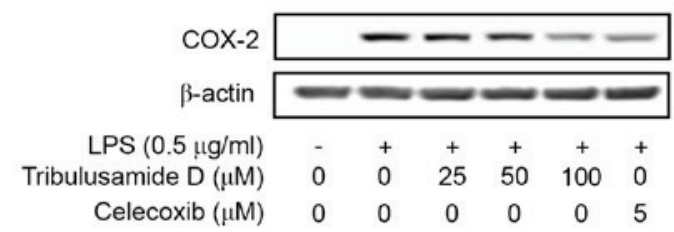

$\mathrm{C}$

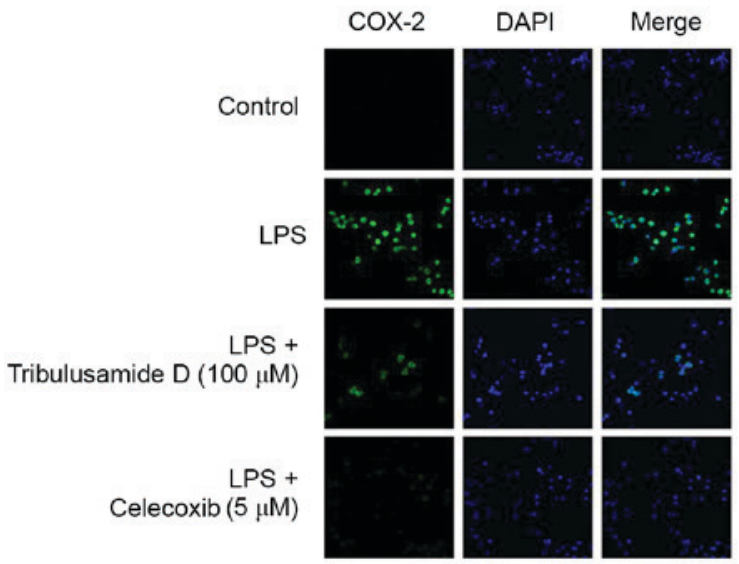

Figure 3. Regulatory effect of tribulusamide D on COX-2 expression in LPS-stimulated RAW 264.7 cells. Cells were treated with tribulusamide D $(25-100 \mu \mathrm{M})$ for $1 \mathrm{~h}$ prior to LPS $(0.5 \mu \mathrm{g} / \mathrm{ml})$ stimulation for $24 \mathrm{~h}$. (A) Expression of COX-2 mRNA was determined by reverse transcription-polymerase chain reaction. (B) Expression of COX-2 protein was determined by western blotting. (C) Cellular expression of COX-2 was microscopically detected by immunofluorescence. Magnification, x200. DNA was stained with DAPI. COX-2, cyclooxygenase-2; LPS, lipopolysaccharide.

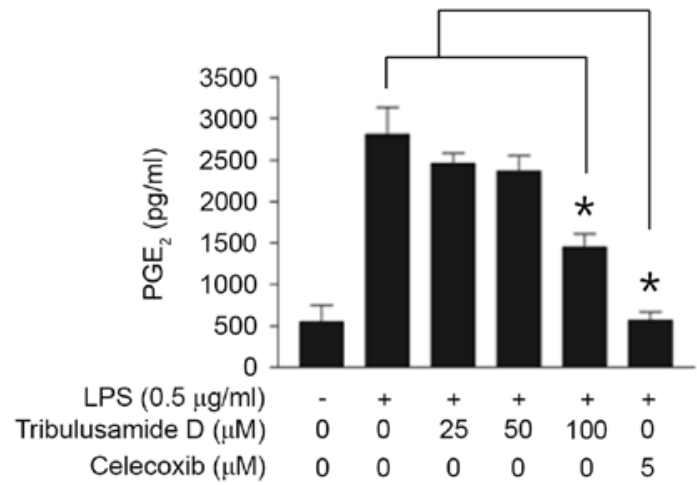

Figure 4. Regulatory effect of tribulusamide $\mathrm{D}$ on $\mathrm{PGE}_{2}$ production in LPS-stimulated RAW 264.7 cells. Cells were treated with tribulusamide D $(25-100 \mu \mathrm{M})$ for $1 \mathrm{~h}$ prior to LPS $(0.5 \mu \mathrm{g} / \mathrm{ml})$ stimulation for $24 \mathrm{~h}$ Quantitative measurement of $\mathrm{PGE}_{2}$ level was performed by using cell culture supernatants. Data are presented as the mean \pm standard deviation of three independent experiments. ${ }^{*} \mathrm{P}<0.05$ vs. LPS-treated cells. $\mathrm{PGE}_{2}$, prostaglandin E2; LPS, lipopolysaccharide.
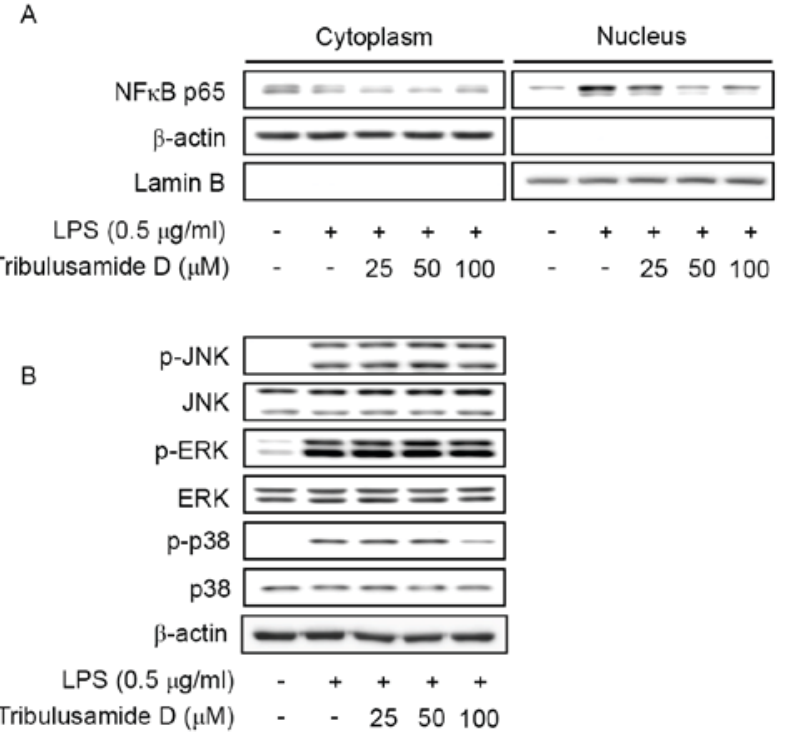

Figure 5. Regulatory effect of tribulusamide D on NF- $\mathrm{B}$ nuclear localization and phosphorylation of p38 mitogen-activated protein kinase in LPS-stimulated RAW 264.7 cells. Cells were treated with tribulusamide D $(25-100 \mu \mathrm{M})$ for $1 \mathrm{~h}$ prior to LPS $(0.5 \mu \mathrm{g} / \mathrm{ml})$ stimulation for $30 \mathrm{~min}$. (A) Cytosolic and nuclear extracts were analyzed via western blot analysis with anti-NF- $\kappa$ B p65, anti- $\beta$-actin or anti-lamin B antibodies. (B) Cell lysates were subjected to western blot analysis with anti-p-ERK, anti-ERK, anti-p-JNK, anti-JNK, anti-p-p38 and anti-p38 antibodies. Results are representative of at least three independent replicates. NF- $\kappa \mathrm{B}$, nuclear factor- $\kappa \mathrm{B}$; LPS, lipopolysaccharide; p-, phospho-; JNK, c-Jun N-terminal kinase; ERK, extracellular signal-regulated kinase.

performed to further demonstrate the effect of tribulusamide D on LPS-induced COX-2 expression. As presented in Fig. 3C, anti-COX-2 staining was strong in LPS-stimulated cells. By contrast, tribulusamide D treatment $(100 \mu \mathrm{M})$ clearly reduced LPS-induced COX-2 immunoreactivity signals. In addition, the effect of tribulusamide $\mathrm{D}$ on the production and release of $\mathrm{PGE}_{2}$, which is a mediator of inflammation, was investigated. The level of $\mathrm{PGE}_{2}$ in the conditioned media of LPS-induced cells was increased compared with control cells, however, treatment with $100 \mu \mathrm{M}$ of tribulusamide D significantly decreased the level of $\mathrm{PGE}_{2}$ compared with LPS-only cells (Fig. 4). Treatment with celecoxib $(5 \mu \mathrm{M})$, which is a COX-2 selective nonsteroidal anti-inflammatory drug, also markedly inhibited the expression of COX-2 at mRNA and protein levels, and significantly reduced $\mathrm{PGE}_{2}$ levels compared with LPS-only cells. The results indicate that tribulusamide D may suppress the production of the inflammatory mediator $\mathrm{PGE}_{2}$ by downregulating the expression of COX-2 in LPS-stimulated RAW 264.7 cells.

Effects of tribulusamide D on LPS-Induced nuclear localization of $N F-\kappa B$ and phosphorylation of MAPKs in RAW 264.7 cells. To further investigate the molecular mechanisms by which tribulusamide D regulates the LPS-induced inflammatory response, the present study investigated whether tribulusamide $\mathrm{D}$ regulates the translocation of $\mathrm{NF}-\kappa \mathrm{B}$ into the nucleus and the changes in activation of mitogenic signaling pathways, including ERK, JNK and p38 MAPK, which have pivotal roles in inflammatory responses (26-28). Initially, the effect of tribulusamide $\mathrm{D}$ on nuclear translocation of $\mathrm{NF}-\kappa \mathrm{B}$ in 
LPS-stimulated RAW 264.7 cells was examined. As demonstrated in Fig. 5A, LPS stimulation for $30 \mathrm{~min}$ induced the nuclear localization of $\mathrm{NF}-\kappa \mathrm{B}$ in the nuclear compartments, and tribulusamide D treatment reduced LPS-induced nuclear localization of $\mathrm{NF}-\kappa \mathrm{B}$. In order to confirm the regulatory effect of tribulusamide D on the LPS-induced inflammatory response, changes in activation of ERK, JNK and p38 MAPK were analyzed. As presented in Fig. 5B, tribulusamide D treatment $(100 \mu \mathrm{M})$ markedly inhibited LPS-induced phosphorylation/activation of p38 MAPK, however, no effects on the phosphorylation of ERK and JNK were observed. The results indicate that tribulusamide D may exert anti-inflammatory effects through inhibition of NF- $\mathrm{B}$ and p38 MAPK signaling pathways.

\section{Discussion}

Previous studies have explored the development of novel medicinesusingnaturalproducts.T.terrestrishasbeenpreviously used as a traditional Chinese medicine for the treatment of high blood pressure, eye disease and edema (29,30). We previously reported that the $80 \%$ ethanol extract of $T$.terrestris dose-dependently inhibited NO production in LPS-stimulated RAW 264.7 cells (24). In another study, we isolated a novel compound, tribulusamide $\mathrm{D}$, from the ethanol extract of $T$. terrestris and demonstrated that it has the potential to suppress NO production in LPS-stimulated RAW 264.7 cells (11). However, the anti-inflammatory effect and the underlying molecular mechanism of tribulusamide D were unclear.

The present study investigated the effect of tribulusamide D on LPS-induced stimulation of the inflammatory response and the expression of pro-inflammatory cytokines. NO is a pleiotropic inflammatory mediator, and it is generated by iNOS. iNOS is considered an important inducible enzyme that regulates inflammatory responses (31). The regulatory effect of tribulusamide D on NO production and iNOS expression in LPS-stimulated RAW 264.7 cells was examined, and the results demonstrated that tribulusamide D treatment significantly inhibited NO production, and reduced the mRNA and protein expression of iNOS. These results indicate that tribulusamide D may suppress LPS-induced NO production by downregulating the expression of iNOS in macrophages. Subsequently, the present study determined whether tribulusamide D has an effect on the expression of COX-2, which has been implicated as an important enzyme in the inflammatory process (32). Previous studies have indicated that COX-2 and iNOS are transcriptionally induced in response to bacterial endotoxins and pro-inflammatory cytokines in macrophages $(33,34)$. COX-2 is induced by inflammation or cytokines and is associated with the synthesis of $\mathrm{PGE}_{2}(32)$. The current study demonstrated that the expression of COX-2 was increased following LPS treatment, and that its expression was reduced by tribulusamide D treatment at the mRNA and protein levels. The results were confirmed by immunofluorescence analysis. As demonstrated the present study, tribulusamide D treatment markedly reduced LPS-induced COX-2 immunoreactivity signals. The levels of another important inflammatory mediator, $\mathrm{PGE}_{2}$, were also measured, and it was observed that levels were decreased significantly by tribulusamide D treatment $(100 \mu \mathrm{M})$. The results demonstrate that tribulusamide $\mathrm{D}$ may inhibit the production of $\mathrm{PGE}_{2}$ by suppression of COX-2 expression in LPS stimulated-RAW 264.7 cells.

It is established that IL-6, IL-10 and TNF- $\alpha$ have key roles in the induction and inhibition of the immune reactions of other inflammatory mediators. TNF- $\alpha$ is an element of the innate immune response against stimuli, and IL- 6 and IL-10 are the most important pro-inflammatory cytokines. The present study demonstrated that the mRNA and protein concentration of IL-6, IL-10 and TNF- $\alpha$ were decreased in LPS-stimulated cells treated with $100 \mu \mathrm{M}$ of tribulusamide D. NF- $\kappa \mathrm{B}$ and MAPKs signaling pathway has a critical role in the regulation of inflammatory gene expression $(35,36)$. The present study also demonstrated that tribulusamide D treatment inhibited LPS-induced nuclear localization of NF- $\kappa \mathrm{B}$ and phosphorylation of p38 MAPK.

In conclusion, the results of the present study demonstrated that tribulusamide D isolated from $T$. terrestris has potential anti-inflammatory effects, which may occur through the suppression of inflammatory mediators and cytokines, by downregulating the enzymes responsible for their production, and associated signaling pathways in LPS-stimulated RAW264.7 cells. To the best of our knowledge, this is the first report demonstrating the anti-inflammatory activity of tribulusamide D in inflammatory responses. Combined, the results of the current study indicate that tribulusamide $\mathrm{D}$ may be a potential therapeutic agent for the treatment of inflammation-associated diseases.

\section{Acknowledgements}

The present study was conducted by the research fund of Dankook University in 2015.

\section{References}

1. Yuan WH, Wang NL, Yi YH and Yao XS: Two Furostanol Saponins from the Fruits of Tribulus terrestris. Chin J Nat Med 6: 172-175, 2008

2. Al-Ali M, Wahbi S, Twaij H and Al-Badr A: Tribulus terrestris: Preliminary study of its diuretic and contractile effects and comparison with Zea mays. J Ethnopharmacol 85: 257-260, 2003.

3. Baburao B, Rajyalakshmi G, Venkatesham A, Kiran G, Sunder A and Rao B: Anti-inflammatory and antimicrobial activities of methanolic extract of Tribulus terrestris Linn plant. I Chem Sci 7: 1867-1872: 2009.

4. Do J, Choi S, Choi J and Hyun JS: Effects and mechanism of action of a Tribulus terrestris extract on penile erection. Korean J Urol 54: 183-188, 2013.

5. Hammoda HM, Ghazy NM, Harraz FM, Radwan MM, ElSohly MA and Abdallah II: Chemical constituents from Tribulus terrestris and screening of their antioxidant activity. Phytochemistry 92: 153-159, 2013.

6. Hussain AA, Mohammed AA, Ibrahim $\mathrm{HH}$ and Abbas AH: Study the biological activities of Tribulus terrestris extracts. Int J Innov Res Sci Eng Technol 57: 433-435, 2009.

7. Mishra NK, Biswal GS, Chowdary KA and Mishra G: Anti-arthritic activity of Tribulus terrestris studied in Freund's Adjuvant induced arthritic rats. J Pharm Educ Res 4: 41, 2013.

8. Phillips OA, Mathew KT and Oriowo MA: Antihypertensive and vasodilator effects of methanolic and aqueous extracts of Tribulus terrestris in rats. J Ethnopharmacol 104: 351-355, 2006.

9. Wu TS, Shi LS and Kuo SC: Alkaloids and other constituents from Tribulus terrestris. Phytochemistry 50: 1411-1415, 1999.

10. Gomathi S, Shanmugapriya A, Bharathi V, Gayathri G and Karpagam T: Antimicrobial activity and phytochemical studies of aqueous and ethanolic fruit extracts of Tribulus terrestris. IJPI's J Pharmacogn Herb Formul 2: 47-51, 2012. 
11. Hong SS, Jeong W, Kwon JG, Choi YH, Ahn EK, Ko HJ, Seo DW and Oh JS: Phenolic amides from the fruits of Tribulus terrestris and their inhibitory effects on the production of nitric oxide. Bull Korean Chem Soc 34: 3105-3108, 2013.

12. Yoon WJ, Ham YM, Kim SS, Yoo BS, Moon JY, Baik JS, Lee NH and Hyun CG: Suppression of pro-inflammatory cytokines, iNOS, and COX-2 expression by brown algae Sargassum micracanthum in RAW 264.7 macrophages. Eur Asia J BioSci 3: $130,2009$.

13. Kim KN, Heo SJ, Yoon WJ, Kang SM, Ahn G, Yi TH and Jeon YJ: Fucoxanthin inhibits the inflammatory response by suppressing the activation of NF- $\kappa \mathrm{B}$ and MAPKs in lipopolysaccharide-induced RAW 264.7 macrophages. Eur J Pharmacol 649: 369-375, 2010

14. Li DY, Xue MY, Geng ZR and Py C: The suppressive effects of Bursopentine (BP5) on oxidative stress and NF- $\mathrm{kB}$ activation in lipopolysaccharide-activated murine peritoneal macrophages. Cell Physiol Biochem 29: 9-20, 2012.

15. Medzhitov R: Inflammation 2010: New adventures of an old flame. Cell 140: 771-776, 2010.

16. Hayden MS, West AP and Ghosh S: NF-kappaB and the immune response. Oncogene 25: 6758-6780, 2006.

17. Yoon WJ, Ham YM, Kim KN, Park SY, Lee NH, Hyun CG and Lee WJ: Anti-inflammatory activity of brown alga Dictyota dichotoma in murine macrophage RAW 264.7 cells. J Med Plant Res 3: 1-8, 2009.

18. Esposito $\mathrm{E}$ and Cuzzocrea $\mathrm{S}$ : The role of nitric oxide synthases in lung inflammation. Curr Opin Invest Drugs 8: 899-909, 2007.

19. Hla T and Neilson K: Human cyclooxygenase-2 cDNA. Proc Natl Acad Sci USA 89: 7384-7388, 1992

20. Murakami A and Ohigashi H: Targeting NOX, INOS and COX-2 in inflammatory cells: Chemoprevention using food phytochemicals. Int J Cancer 121: 2357-2363, 2007.

21. O'Sullivan MG, Chilton FH, Huggins EM Jr and McCall CE: Lipopolysaccharide priming of alveolar macrophages for enhanced synthesis of prostanoids involves induction of a novel prostaglandin H synthase. J Biol Chem 267: 14547-14550, 1992.

22. Lee SJ, Bai SK, Lee KS, Namkoong S, Na HJ, Ha KS, Han JA, Yim SV, Chang K, Kwon YG, et al: Astaxanthin inhibits nitric oxide production and inflammatory gene expression by suppressing I(kappa)B kinase-dependent NF-kappaB activation. Mol Cells 16: 97-105, 2003

23. Kim HJ, Lee HS, Chong YH and Kang JL: 38 mitogen-activated protein kinase up-regulates LPS-induced NF-kappaB activation in the development of lung injury and RAW 264.7 macrophages. Toxicology 225: 36-47, 2006.
24. Ko HJ, Ahn EK and Oh JS: N-trans- $\rho$-caffeoyl tyramine isolated from Tribulus terrestris exerts anti-inflammatory effects in lipopolysaccharide-stimulated RAW 264.7 cells. Int J Mol Med 36: 1042-1048, 2015.

25. Olken NM and Marletta MA: NG-Methyl-L-arginine functions as an alternate substrate and mechanism-based inhibitor of nitric oxide synthase. Biochemistry 32: 9677-9685, 1993.

26. Ghosh S and Hayden MS: New regulators of NF-kappaB in inflammation. Nat Rev Immunol 8: 837-848, 2008.

27. Ben-Neriah Y and Karin M: Inflammation meets cancer, with $\mathrm{NF}-\kappa \mathrm{B}$ as the matchmaker. Nat Immunol 12: 715-723, 2011.

28. Hommes DW, Peppelenbosch MP and van Deventer SJ: Mitogen activated protein (MAP) kinase signal transduction pathways and novel anti-inflammatory targets. Gut 52: 144-151: 2003.

29. Shaheen G, Ahmad I, Usmanghani K, Akhter N, Ahmad M, Sultana $S$ and Akram M: Monograph of Tribulus terrestris. J Med Plants Res 6: 641, 2012.

30. Xu T, Xu Y, Liu Y, Xie S, Si Y and Xu D: Two new furostanol saponins from Tribulus terrestris L. Fitoterapia 80: 354-357, 2009.

31. Surh YJ, Chun KS, Cha HH, Han SS, Keum YS, Park KK and Lee SS: Molecular mechanisms underlying chemopreventive activities of anti-inflammatory phytochemicals: Down-regulation of COX-2 and iNOS through suppression of NF-kappa B activation. Mutat Res 480-481: 243-268, 2006.

32. Simmons DL, Botting RM and Hla T: Cyclooxygenase isozymes: The biology of prostaglandin synthesis and inhibition. Pharmacol Rev 56: 387-437: 2004.

33. Britten N, Waldron N, Watts J and Hallberg J: Cyclooxygenase-2 inhibitor and antibacterial agent combination for intramammary treatment of mastitis. US Patent 20040033938 A1. Filed March 20, 2003; issued February 19, 2004.

34. Kim MS, Ahn EK, Hong SS and Oh JS: 2,8-Decadiene-1,10-Diol inhibits lipopolysaccharide-induced inflammatory responses through inactivation of Mitogen-Activated Protein Kinase and Nuclear Factor- $\kappa$ B signaling pathway. Inflammation 39: 583-591, 2016.

35. Karin M: Nuclear factor-kappaB in cancer development and progression. Nature 441: 431-436, 2006.

36. Carter AB, Knudtson KL, Monick MM and Hunninghake GW: The p38 mitogen-activated protein kinase is required for NF-kappaB-dependent gene expression: The role of TATA-binding protein (TBP). J Biol Chem 274: 30858-30863, 1999. 